\title{
Fungal Diversity in Gujarat University Campus in Different Seasons
}

\author{
Kalpa Oza ${ }^{1}$, Archana Mankad ${ }^{2}$ \\ Department of Botany, Bioinformatics, Climate Change Impacts Management, University School of Sciences, Gujarat University, \\ Ahmedabad-380009, Gujarat, India
}

\begin{abstract}
Fungi were isolated from soil of Gujarat University campus from different locations between November 2013 to October 2014. Fungi were isolated by serial dilution and spread plate method. Isolated strains were identified by their cultural, morphological and microscopic characteristic as Aspergillusniger, Fusariumsp, Penicilliumsp etc. Total 24 isolates were obtained into 5 soil samples. Aspergillusniger shows highest contributed in diversity.
\end{abstract}

Keywords: fungal isolates, soil, diversity, season

\section{Introduction}

The mixture of minerals, organic matter, gases, liquids and myriad organisms that together support the plant life is known as soil (Palczar M T, 2005). Soil fungi are involved with plant roots and forms of symbiosis, namely mutualistic associations. In symbiosis, the fungus obtains photo synthetically derived carbon compound while the host plant receives mineral nutrients (Harley and Smith, 1983). Anatomical, morphological and sometimes chemical characters are based on the description of fungal species. New species of fungi to be accepted still require Latin names as recommended by the International Code of Botanical Nomenclature (McNeil et.al, 2006). The code is followed by mycologists to name the fungi. The new species also require the deposition of voucher specimen in official collections (Branco, 2011).

\section{Material and Method}

\section{Sample collection}

Fungal sample isolated from soil, they were collected from 5 different areas of Gujarat University campus i.e. Front side of Horticulture lab -Ficusbenghalensis (Banyan tree), Behind of Botany department Peltophorumferaginium, Front side of Microbiology lab - Phyllostachysaurea (Golden bamboo), Front side of main Tower's garden Festucaarundinacea (Lawn), Behind theRollwala computer center (Dung fertilizer). The samples were collected in three different seasons i.e. Winter, summer and rainy seasons. The soil sample should be dry for further processing so first the samples were air dried at room temperature at $27^{\circ} \mathrm{C}$ for few hours or 2 - 3 days. After soil samples become dry,and thenthey were sieved with $0.5 \mathrm{~mm}$ sieve to remove large particles such as stones and plant debris to smoothen soil sample.

\section{Media preparation}

PDA is commonly used media for fungi. Each and every type of fungal isolate was grown on Potato Dextrose Agar Medium (PDA).
The medium contains:-

Potato extract - $200 \mathrm{ml}$

Dextrose - 20 gram

Agar agar - 20 gram

Distilled water - $1000 \mathrm{ml}$

Isolation of fungi from serial dilution method - Serial dilution method is one of the commonly used methods. This method is based upon the principle that when material containing microorganism is grown, different microorganism grow into a colony form, hence the number of colonies that grow on the Petri dish shows the number of living microorganism present in the sample (Aneja, 2012).

Slide preparation- The Lacto- phenol Cotton Blue is a stain which is used for staining fungal cell. For the preparation 3 components are essential: phenol, which will kill any living organisms, lactic acid which preserves fungal structure and cotton blue which stain the chitin in the fungal cell wall. The samples were immersed in a drop of alcohol. Only two drop of lacto phenol or cotton blue stain is needed and then slides are observed under the microscope.

Identification of fungi- The identification of isolated fungi up to the genus and species is possible on the basis of macro morphological and micro morphological characteristics, using manuals of fungi i.e. Manual of soil fungi (Gilman , 1998), illustrated Genera of imperfect fungi (Barnett, 1965), Hyphomycetes (Subramanian, 1971), Dematiaceous Hyphomycetes and Dematiaceous Hyphomycetes (Ellis, 1971, 1976) and Micro fungi on land plants (Ellis and Ellis, 1985) Micro fungi on Miscellaneous substrate (Ellis and Ellis, 1988). Artificial Identification Key (Ellis, 1971, 1976).

\section{Result}

During the present investigation total 24 fungal genera isolated were from soil samples like Aspergillus, Cladosporium, Fusarium, Penicillium, Rhizopusspecies were observed. The soil mycoflora in different season were observed. Total 24 isolates found, where 17 isolates are identified, 8 isolates are unidentified and 3 isolates (Aspergillusflavas, A. niger and Penicilliumcitrinum) are common in all seasons. There comparative percentage frequency was statistically analyzed and shown in table 1 , figure 1. 


\section{International Journal of Science and Research (IJSR) \\ ISSN (Online): 2319-7064}

Index Copernicus Value (2015): 78.96 | Impact Factor (2015): 6.391

It was a seasonal study so as compared to summer and winter in rainy season many isolates were obtained. July to October was favorable condition of fungal growth due to medium temperature moist wind and percentage of humidity that is very high in environment.

Table 1: Comparative study of richness of fungal isolates during summer, rainy and winter season.

\begin{tabular}{|c|c|c|c|c|}
\hline s.no. & Fungal Name & $\begin{array}{c}\text { Summar } \\
\text { Cfu value }\end{array}$ & $\begin{array}{c}\text { Rainy } \\
\text { Cfu value }\end{array}$ & $\begin{array}{c}\text { Winter } \\
\text { Cfu value }\end{array}$ \\
\hline 1 & Aureobasidium sp. & 0 & $\mathbf{3 . 5}$ & 0 \\
\hline 2 & Aspergillus sp. & 0 & $\mathbf{3}$ & 2 \\
\hline 3 & Aspergilluscandidus & 6.5 & $\mathbf{2}$ & 0 \\
\hline 4 & Aspergillusflavus & 7.5 & $\mathbf{7 . 5}$ & 2.5 \\
\hline 5 & Aspergillusniger & $\mathbf{1 0}$ & $\mathbf{9}$ & $\mathbf{7}$ \\
\hline 6 & Aspergillusnidulas & 7.5 & $\mathbf{1 4}$ & 0 \\
\hline 7 & Bipolaris sp. & 0 & $\mathbf{3}$ & 0 \\
\hline 8 & Cladosporiumoxyspoyum & 2 & $\mathbf{0}$ & 0 \\
\hline 9 & Fusariumoxysporum & 0 & $\mathbf{5}$ & 3 \\
\hline 10 & Mortierella sp. & 0 & $\mathbf{5 . 5}$ & 0 \\
\hline 11 & Oedoeephalumsp & 0 & $\mathbf{5}$ & 0 \\
\hline 12 & Penicilliumcitrinum & $\mathbf{3 . 5}$ & $\mathbf{1 . 5}$ & $\mathbf{2}$ \\
\hline 13 & Rhizopussp & 0 & $\mathbf{8 . 5}$ & 0 \\
\hline 14 & Rhizopusoryzae & 7 & $\mathbf{0}$ & 0 \\
\hline
\end{tabular}

Figure 1: Comparative study of seasonal variation on diversity of mycoflora at Gujarat University campus.

\section{References}

[1] Aneja, K. R. (2012). Experimental Microbiology. Plant pathology and Biotechnology. (4th ed.). New Age International Publisures

[2] Branco, Sara (2011). Fungal Diversity: An Overview. The Dynamical Processes of Biodiversity - Case Studies of Evolution and Spatial Distribution, PhD. Oscar Grillo (Ed.)

[3] Barnett, H. L. and Hunter, B. B. (1965) . Illustrated genera of imperfect fungi. (4th ed.)

[4] Ellis, M. B. (1971). Dematiaceoushyphomycetes, Kew. Surrey.UK: Commonwealth Mycological Institute

[5] Ellis, M. B. and Ellis, J.P. (1985) . Micro fungi on land plants: an identification hand book. London: Croom Helm

[6] Gilman, J.C. (1998). A manual of soil fungi. New Delhi: Biotech Books

[7] Harley, J. L. and Smith, S. E. (1983). Mycorrhizal Symbiosis. Toronto : Academic Press

[8] Palczar, M. T. (2005). Microbiology. (5th ed). McGraw Hill Education

[9] Subramanian, C.V. (1971). Hyphomycetes: an account of Indian species except cercosporae. New Delhi: ICAR

\begin{tabular}{|c|c|c|c|c|}
\hline 15 & Rhizopusstolonifer & 8 & $\mathbf{3 . 5}$ & 0 \\
\hline 16 & Rhizopus reproductive & 0 & - & 4 \\
\hline 17 & $\begin{array}{c}\text { Talaromyces stage of } \\
\text { Aspergillus }\end{array}$ & 0 & $\mathbf{2}$ & 0 \\
\hline 18 & Unknown 1 & 0 & $\mathbf{4}$ & 0 \\
\hline 19 & Unknown 2 & 0 & $\mathbf{3}$ & 0 \\
\hline 20 & Unknown 3 & 0 & $\mathbf{2}$ & 0 \\
\hline 21 & Unknown 4 & 2 & $\mathbf{0}$ & 0 \\
\hline 22 & Unknown 5 & 1.5 & $\mathbf{0}$ & 0 \\
\hline 23 & Unknown 6 & 4 & $\mathbf{0}$ & 0 \\
\hline 24 & Unknown 8 & 0 & $\mathbf{0}$ & 3 \\
\hline
\end{tabular}

\section{Discussion}

The soil samples obtained from different locations on Gujarat University Campus exhibited near total similarity in fungal diversity. Although minor difference of presence and absence of certain fungal sps.was noteworthy, the campus soil contains edentate diversity of basidiomycetes and dueteromycetes soil fungi. Saprobic fungi play a very significant role in solid waste management and biodegradation so its growth and production is significant for sustainable soil health. 